\title{
1: 211175452-211226309
}

National Cancer Institute

\section{Source}

National Cancer Institute. 1:211175452-211226309. NCI Thesaurus. Code C41953.

Physical location of CENPF_Gene 